Article

\title{
Design, Simulation, and Economic Optimization of an Off-Grid Photovoltaic System for Rural Electrification
}

\author{
Haytham El-houari ${ }^{1,2,3, *}$, Amine Allouhi ${ }^{1}$, Shafiqur Rehman ${ }^{4}{ }^{\circ}$, Mahmut Sami Buker ${ }^{5}$, \\ Tarik Kousksou ${ }^{3}$, Abdelmajid Jamil ${ }^{1}$ and Bouchta El Amrani ${ }^{2}$ \\ 1 Ecole Supérieure de Technologie de Fès, U.S.M.B.A, Route d'Imouzzer, Fez BP. 242, Morocco; \\ allouhiamine@gmail.com (A.A.); abdelmajid.jamil@gmail.com (A.J.) \\ 2 Ecole Normale Supérieure de Fès, U.S.M.B.A, Route Bensouda, Fez BP. 5206, Morocco; amrani_b@yahoo.fr \\ 3 Laboratoire des Sciences de l'Ingénieur Appliquées à la Mécanique et au Génie Electrique (SIAME), \\ Université de Pau et des Pays de l'Adour-IFR-A. Jules Ferry, 64000 Pau, France; tkousks@gmail.com \\ 4 Center for Engineering Research, King Fahd University of Petroleum and Minerals, \\ Dhahran 31261, Saudi Arabia; srehman@kfupm.edu.sa \\ 5 Department of Aeronautical Engineering, Konya NEU University, 42090 Konya, Turkey; \\ msbuker@konya.edu.tr \\ * Correspondence: haythamelhouari1@gmail.com
}

Received: 18 November 2019; Accepted: 7 December 2019; Published: 12 December 2019

\begin{abstract}
Access to clean and affordable energy in rural African regions can contribute greatly to social development. Hence, this article proposes the design, simulation, and optimization of a stand-alone photovoltaic system (SAPV) to provide non-polluting electrical energy based on a renewable source for a rural house located in Tazouta, Morocco. Real monthly electrical demands and hourly climatic conditions were utilized. An initial design process indicated that, with a $1080 \mathrm{~W}_{\mathrm{p}}$ total capacity of PV modules and 670 Ah of battery storage, the proposed SAPV system was able to meet a considerable part of the dwelling load with an average solar fraction of about $79.1 \%$. The rest of the energy demand was ensured by a diesel generator (DG). Also, a life cycle analysis of the PV system revealed that the life cycle cost is 10,195.56 USD and the unit electricity cost is $0.57 \mathrm{USD} / \mathrm{kWh}$ for an initial investment of 4858.68 USD. Thereafter, an optimum design based on Homer Pro software was carried out indicating that lower PV capacity can decrease the unit energy cost to $0.356 \mathrm{USD} / \mathrm{kWh}$ while reducing the solar fraction to $54.9 \%$.
\end{abstract}

Keywords: photovoltaic; off-grid; design; simulation; life cycle cost analysis; optimization; Morocco

\section{Introduction}

The globally increasing population and the equally growing energy need have become alarming in recent years. Although this concern is made up of several aspects, one main issue to combat is environmental degradation due to major power production from fossil fuels. Moreover, since providing power and water to all communities has become very difficult and expensive, we must rebuild our infrastructure and find new ways to use clean sources of energy. This approach has a double benefit in that the use of renewable and clean sources of energy will lead towards reduction in greenhouse gas emissions into the atmosphere and will be able to provide power anywhere irrespective of the grid or means of transportation. Thus, solar photovoltaic (PV) technology has been emerging at an ever-increasing pace due to mature technology and cost effective energy production.

Today, electricity is one of the most important resources for the promotion of society from the view point of economic and social development and it is, now, considered as a fundamental need of modern 
society [1]. Access to electricity has not only been identified as an essential element for socio-economic development, but also contributes towards poverty reduction in society [2]. However, electricity generation and its supply are not distributed equally in the world, especially in rural regions [3-5] that also suffer from the low quality of the power supply distribution services [6,7]. Yet, most of African countries, for instance, are still underdeveloped both in terms of infrastructure and power network, despite large, ongoing renewable energy projects in the region. In fact, there are about 620 million people in this continent that have no access to electricity, which is equivalent to two-thirds of Africa's population [8].

Of the 315 million people in rural Africa who are expected to have access to electricity by 2040, only $30 \%$ of them will be connected to national networks. The others will be connected to off-grid or mini-grid power systems [9]. Kofi Annan, chairman of the Africa Progress Panel and former UN secretary general urged African governments and their partners to do their utmost to combat the enormous energy deficit in Africa. This joint appeal was launched on Monday, 13 March 2017, at the ADB headquarters in Abidjan, Ivory Coast on the occasion of the launch of the Africa Progress Panel report entitled "Light, Energy, Action: Electrifying Africa", which calls for adopting all existing solutions—-network and off-grid systems—-to illuminate Africa and power it [10].

It is no great surprise as this continent has an abundant potential of solar, hydro, wind, and geothermal sources of energy and contains significant quantities of natural gas. Some countries even have coal deposits. The great challenge for Africa is to exploit and manage these resources and make them contribute to its economic development and ease for the inhabitants. Morocco, which belongs to the northern African countries, fulfills its energy needs from about $96 \%$ of imported fossil fuels. However, the country possesses significant resources of renewable energy, especially solar and wind. Ensuring uninterrupted energy supply to the community is an important priority of the public authorities in Morocco, in addition to achieving sustainable development and new job creation [11]. More importantly, Morocco receives an enormous amount of solar radiation every day and has sufficient land for its exploitation [11,12]. For example, the average sunshine duration per year is about 5000 hours with an average $5.3 \mathrm{kWh} / \mathrm{m}^{2}$ of the daily solar radiation [13].

In Morocco, the average greenhouse gas (GHG) emission rate is estimated to be 2.8 tons of $\mathrm{CO}_{2} /$ year/capita and is considered low relative to world norms [14]. However, with population growth and industrial development, this ratio is expected to increase in the near future [15,16]. As electricity may cost more in rural areas, only high-income group communities can afford it $[17,18]$. Nevertheless, for low-income populations, diesel generators are often used [19].

Based on the available solar resources, it is believed that solar energy can play a major role in providing electricity based on a stand-alone photovoltaic (SAPV) system to the Moroccan rural areas. The proposed SAPV system, in this communication, is an independent system that converts solar energy directly into electricity [20]. So, the prominent advantages of photovoltaic solar technology can be outlined as the capability of allowing clean production of electricity with almost $0 \%$ of $\mathrm{CO}_{2}$ emissions, ease to maintain-and-operate, and also high reliability. As such, the overall cost of operation and maintenance of such systems is minimal and does not require skilled manpower [21-23].

\section{Literature Review}

Extensive research has been carried out to resolve the design, modeling, simulation, feasibility, viability, economics, application and control of off-grid/standalone PV electrification systems [24,25]. Research was performed extensively on optimum design, modeling, simulation, and feasibility study of standalone solar PV systems either ground mounted or rooftop for electrification [26-33]. Kuandinya et al. [34] compared several models to analyze the technical viability of off-grid PV electrification systems i.e. cost effectiveness, leveled energy cost approach, annualized life cycle cost and financial indicators. Roy and Kabir [35] compared an off-grid PV system with conventional fossil fuel driven power sources to decide on its technical success in the rural part of Bangladesh having no access to the electricity grid, and performed life cycle analysis to focus on the planning of financial 
matters of small to medium size renewable projects. Nafeh et al. [36] proposed a stand-alone off-grid PV for a single household in a remote site of the Sinai Peninsula, Egypt. The PV module area was decided to be $11.3 \mathrm{~m}^{3}$ along with $1365 \mathrm{~W}_{\mathrm{P}}$ of peak power to meet $5.5 \mathrm{kWh} / \mathrm{d}$ of average daily load using six batteries ( $250 \mathrm{~A} \mathrm{~h}, 12 \mathrm{~V}$ ). The unit cost of electricity was estimated to be $0.74 \mathrm{USD} \mathrm{kWh} / \mathrm{d}$. Oko et al. [37] designed a stand-alone PV system for Port Harcourt in Nigeria and carried out economic analysis of the proposed system. The authors concluded that sorting the input data in an automated MS Excel (version, manufacturer, city, state abbreviation if USA and Canada, Country) spread sheet would help in performing design and economic analyses of PV systems in any geographical location. Ma et al. [38] examined the performance characteristics of a standalone PV system for a remote island in Hong Kong and noticed that an increase in the cell temperature would result in a significant decrease in output of the PV system. The actual array output was $3.08 \mathrm{kWh} / \mathrm{kW}_{\mathrm{p}} / \mathrm{d}$ against the anticipated $4.9 \mathrm{kWh} / \mathrm{kW}_{\mathrm{p}} / \mathrm{d}$. Chel and Tiwari [39] conducted a case study for a typical $2.32 \mathrm{~kW}_{\mathrm{p}}$ standalone PV system in New Delhi, India and tested the system under four different weather conditions such as clear, hazy, partially cloudy/foggy, and fully cloudy/foggy conditions. The system generated a total of $1293 \mathrm{kWh} /$ year as the inverter and system efficiencies were found to be $95.6 \%$ and $4.8 \%$, respectively. Salam et al. [40] executed simulation analysis for optimal sizing of a PV system for a renewable energy laboratory in Sohar, Oman. The optimization results revealed that $0.7 \mathrm{~kW}$ rated capacity of PV array generated $1316 \mathrm{kWh} /$ year and the unit energy cost was found to be $0.561 \mathrm{USD}$ kW/h. Kaplani et al [41] developed a simulation model for optimal sizing of a PV system for various cities in Europe and concluded that solar radiation fluctuation has a substantial impact on the reliability, size, and the cost of the PV system. Al-Karaghouli and Kazmerski [42] also performed simulations of various combinations of $\mathrm{PV}$, battery, and inverter size to provide electricity to a health clinic in a remote site of Southern Iraq. The optimal system was found to comprise $6 \mathrm{~kW}_{\mathrm{p}}$ capacity of PV, 80 batteries $(225 \mathrm{Ah}, 6 \mathrm{~V})$ and $3 \mathrm{~kW}$ inverter. LCC was applied and $0.238 \mathrm{USD} \mathrm{kW} / \mathrm{h}$ was attained as the unit cost of electricity generation. Bhandari and Stadler [43] examined the feasibility of standalone PV systems for rural area electrification in Nepal. They reached the decision that a standalone PV system is not cost effective in urban areas. They also advocated that rural electrification projects should be decided on the basis of social aspects rather than considering monetary benefits. Mandapati [44] studied the design of a PV system for a conference hall in Bhopal that has the daily electrical load of $9.5 \mathrm{kWh} / \mathrm{d}$ The LCC analysis found per unit electricity costs of Indian Rs. $28.99 \mathrm{~kW} / \mathrm{h}$. Byrne et al. [45] performed an economic and livelihoods impacts study on small scale and standalone renewable energy technologies for rural electrification of 531 rural households within three provinces of western China and deduced that off-grid renewable energy systems are cost effective and reliable. Bataineh and Dalalah [46] managed to develop software to specify the optimal design and carry out LCC analysis of standalone PV systems. According to the findings the optimal unit electricity cost was found to be 0.293 USD $\mathrm{kW} / \mathrm{h}^{-}$which proved the viability of exploiting PV systems in a rural site in Jordan. Bhuiyanet al. [47] composed a standalone PV system to electrify residential appliances for $4 \mathrm{~h}$ per day. It was calculated that $282 \mathrm{~W}_{\mathrm{p}}$ of minimum PV and $128 \mathrm{~A} \mathrm{~h}$ of battery capacity were required to operate the residential appliances. Soufi et al. [48] composed an off-grid PV system for electrification of livestock shelters and assessed the performance. The results revealed that the system was composed of a $4 \mathrm{~kW}$ PV array, six dry batteries (200 Ah and $12 \mathrm{~V}$ ) and a $5 \mathrm{~kW} \mathrm{DC-AC} \mathrm{inverter} \mathrm{was} \mathrm{enough} \mathrm{to}$ meet $5.5 \mathrm{kWh}$ daily load with initial capital cost of 9700 USD. The unit cost of electricity, however, was not provided in the study. Saxena et al. [49] designed a PV system to meet the estimated load of 233.17 Ah/d of a biscuit packing machine. One hundred and thirty eight PV modules with an area of $172.23 \mathrm{~m}^{2}$ and 315 batteries were sized for the proposed system and the cost of electricity produced was calculated to be Indian Rs. $15.095 \mathrm{~kW} / \mathrm{h}$. Hassan et al. [50] proposed a stand-alone PV system to electrify an emergency health clinic in Egypt. The analysis including sizing, simulation, and economic assessment of the system showed that a $3.3 \mathrm{~kW} \mathrm{PV}$ array and 20 batteries $(6 \mathrm{~V}, 1156 \mathrm{Ah}, 6.94 \mathrm{kWh})$ were needed to meet the total load of the clinic. The total net present value of the system was calculated to be 48,749 USD corresponding to $7353 \mathrm{kWh}$ of the total annual output from PV array. Similar performance 
studies on stand-alone PV systems have been performed by researchers worldwide. Some of these studies are presented in Table 1.

Table 1. Various studies and progress on standalone PV systems.

\begin{tabular}{|c|c|c|c|c|}
\hline Location & Load & System Specifications & Outcomes & References \\
\hline Tocantis, Brazil & $\begin{array}{l}\text { Total annual load: } \\
8.7 \mathrm{MWh} / \text { year }\end{array}$ & $\begin{array}{c}\text { PV: } 6.28 \mathrm{~kW} \\
\text { Battery: } 16 \mathrm{No} .(12 \mathrm{~V}, \\
220 \mathrm{Ah})\end{array}$ & $\begin{array}{c}\text { Cost of elect.: } \\
0.657 \text { USD/kW/h NPC: } \\
\text { 49,711USD }\end{array}$ & [51] \\
\hline Athens, Greece & $\begin{array}{l}\text { Max load: } 2 \mathrm{kWh} / \mathrm{dWater} \\
\text { pump: } \max 400 \mathrm{~L} / \mathrm{h}\end{array}$ & $\begin{array}{c}\text { PV: } 610 \mathrm{~W}_{\mathrm{p}} \\
\text { Battery: } 4 \text { No. }(12 \mathrm{~V}, 200 \mathrm{Ah})\end{array}$ & $\begin{array}{l}\text { The proposed system is } \\
\text { capable of meeting the load. }\end{array}$ & [52] \\
\hline Thailand & $\begin{array}{c}\text { Total load: } \\
197.83 \mathrm{kWh} / \text { year (1 TV, } 1 \\
\text { fan, } 1 \text { radio and } 3 \text { lamps) }\end{array}$ & $\begin{array}{l}\text { PV: } 220 \mathrm{Kw} \\
\text { Battery: } 250 \mathrm{Ah}\end{array}$ & $\begin{array}{c}\text { Cost of elec.: } \\
1,234 \mathrm{USD} / \mathrm{kW} / \mathrm{h}\end{array}$ & [53] \\
\hline Belgium & - & $3 \mathrm{~kW}_{\mathrm{p}}$ and more (6868 sites) & $\begin{array}{c}\text { Annual energy produced: } \\
1163 \mathrm{kWh} / \mathrm{kW}_{\mathrm{p}} \\
\text { Orientation: } 7 \% \text { less than } \\
\text { optimally oriented } \\
\text { Performance ratio (PR): } 78 \%\end{array}$ & [54] \\
\hline Kerman, Iran & $\begin{array}{l}\text { Annual load for } 50 \text { rural } \\
\text { household: } 24.4 \mathrm{MWh}\end{array}$ & $\begin{array}{c}\text { PV: } 19 \mathrm{~kW}_{\mathrm{p}} \\
\text { Battery: } 12 \mathrm{No} \cdot(2 \mathrm{~V}, \\
3000 \mathrm{Ah})\end{array}$ & $\begin{array}{c}\text { Cost of elec.: } \\
0.247 \text { USD kW/h }\end{array}$ & [55] \\
\hline Bangalore, India & - & PV: $20 \mathrm{~kW}_{\mathrm{p}}$ & $\begin{array}{c}\text { Annual capacity factor: } \\
16.5 \% \\
\text { Performance ratio: } 85 \%\end{array}$ & [56] \\
\hline Umbertide, Italy & - & $\begin{array}{c}\text { PV: } 15 \mathrm{~kW}_{\mathrm{p}}(220 \text { modules, } \\
22 \text { arrays })\end{array}$ & $\begin{array}{l}\text { Efficiency decrease by } \\
\text { temperature: } 0.025 \%\end{array}$ & [57] \\
\hline $\begin{array}{l}\text { Kuala Lumpur, } \\
\text { Malaysia }\end{array}$ & $\begin{array}{c}\text { 6,135 kWh/d } \\
\text { Max power: 0,52 kW } \\
\text { Avg. load power: } \\
0.255 \mathrm{~kW}\end{array}$ & $\begin{array}{l}2,2.1,2.2,2.3,2.6,4.3 \\
\quad \text { (six places) }\end{array}$ & $\begin{array}{l}\text { PV system with } 99 \% \\
\text { availability is suggested due } \\
\text { to high reliability and low } \\
\text { unit cost of energy. }\end{array}$ & [58] \\
\hline
\end{tabular}

As can be seen from the literature review, the design and simulation of SAPV systems for rural electrification has been extensively reported. In fact, meteorological data and financial aspects have a strong impact on the system's economic performance. With the accelerated rate of market development of PV technology, costs have experienced a remarkable decrease. In Morocco, many rural regions are still not connected to the electrical grid which negatively impacts their social development. Drawing realistic conclusions about the use of renewable based power generation systems in such areas constitutes a fundamental point for future national energy policies. In this sense, updated assessment studies considering recent market data are highly recommended for the decision-making process about the best alternatives for rural electrification in Morocco. This paper presents a detailed methodology for selecting the optimum size of the SAPV system based on real energy demands and hourly climatic data for a residential house in the Middle Atlas region of Tazouta, Morocco. The life cycle approach is practiced to examine the economic viability of the designed system. Further optimization is carried out using Homer pro software in an attempt to decrease the unit electricity cost to acceptable limits.

\section{Methodology}

The methodology followed in the current investigation starts by generating the meteorological data of Tazouta using METEONORM (7.1.3, Meteotest, Bern, Schweiz version, manufacturer, city, state abbreviation if USA and Canada, Country). METEONORM software is a complete weather database largely used in modelling various energy systems and processes. It also contains algorithms to calibrate the weather data around the world, with the possibility of adjusting many meteorological parameters. The results can be exported as well to many other types of simulation software to calculate hourly and minute values [59]. Then, data related to energy used were collected for a typical house located in the same rural region. Based on the Moroccan market considerations, an initial sizing procedure was followed to identify the appropriate characteristics the main SAPV components. After preparing the input data required, the simulation of the overall SAPV system was performed using the PVsyst 
software (5.06, PVsyst SA, Satigny, Suisse version, manufacturer, city, state abbreviation if USA and Canada, Country) which is a popular solar photovoltaic panel sizing software that provides various information such as solar irradiation potential estimation, energy production, and installation costs. The exploitation of the information is very practical for elaborating assessment studies related to grid-connected, stand-alone, and PV pumping installations [60]. A life cycle cost analysis was performed to examine the economic viability of the proposed design. Finally, a more optimized configuration was introduced using Homer pro software [61] and the conclusions drawn.

\subsection{Site Description}

The evaluation of the proposed SAPV system for rural residential communities was performed for a rural area namely Tazouta, located in Sefrou province, Morocco. The population in this region, according to the High Commission of Planning (2014) is 6227 with 1354 households. This village belongs to the mountain chain of the Middle Atlas (latitude: $33.672 \mathrm{~N}$, longitude: $4.629 \mathrm{~W}$, elevation: $1128 \mathrm{~m}$ ). It spreads over an area of $174 \mathrm{~km}^{2}$ equivalent to $4.36 \%$ of the provincial total area. Geographically, the village is surrounded by rural towns Ahl Sidi Lahcen and Ouled Mkoudou in the North: by villages Dar lhamra and Adrej in the East: by villages Laanoucer and Sidi Youssef Ben Ahmed in the West: and by villages Guigou and Skoura Mdez in the South.

\subsection{Climatic Conditions}

The geographical location of Tazouta in the central middle mountain of the Atlas impacts its climate. It is semi-humid in general, cold in the winter, and hot in the summer. A total annual precipitation between 350 and $400 \mathrm{~mm}$ is observed. The climatic data, in this study, were derived from METEONORM [60]. Figure 1a shows the monthly average daily global irradiation on the horizontal surface and on an inclined surface at the optimal tilt angle of $30^{\circ}$. The monthly global horizontal irradiation varies between 3.06 and $7.73 \mathrm{kWh} / \mathrm{m}^{2} / \mathrm{d}$. The annual average daily irradiation was estimated to be $5.39 \mathrm{kWh} / \mathrm{m}^{2} / \mathrm{d}$ and annual average temperature was found to be $15{ }^{\circ} \mathrm{C}$ see Figure $1 \mathrm{~b}$. The irradiation values on horizontal and tilted surfaces showed an increasing trend from January towards June and after reaching their peak in June and July, then, started decreasing towards the end of the year. However, the irradiation values on a tilted surface were found to be higher during January to April and August to December.

\subsection{Load Assessment}

The house under investigation consisted of 3 bedrooms, a living room, a kitchen, a dining room and a toilet. The house was unoccupied and its owner needed to make a decision on implementing a SAPV system to fulfill its energy requirements. Similar to other traditional dwellings in Tazouta, this house has also a kitchen (Anoual) separated from the house. It is generally used for baking using wood and animal wastes.

The energy consumption of a typical grid connected electricity which supplies another house in the same region for the year 2016 is shown in Figure 2. The annual energy consumption is found to be $1398 \mathrm{kWh}$, and the peak consumption is observed in the month of July. In fact the energy use in such regions increases in the summer period because of increased family visits and air conditioning use. The lowest energy consumption is observed in November. The daily average energy consumption is found to be $3.831 \mathrm{kWh} / \mathrm{d}$. The number of electrical appliances was determined and it was found that the estimation agrees well with the average daily load deduced from the energy bills as given in Table 2. As a result monthly energy demands were used in the design and simulation processes. 


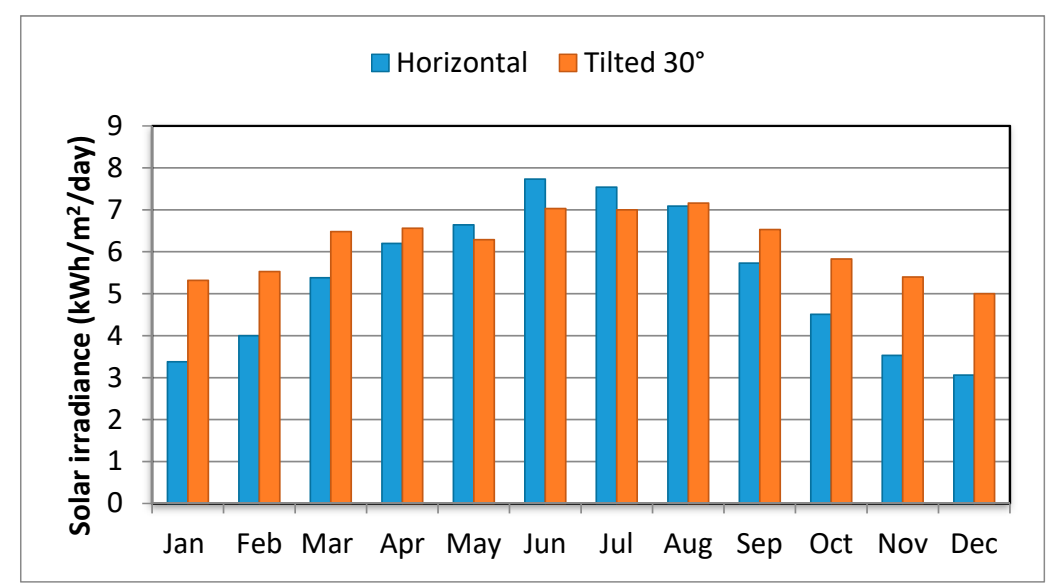

(a)

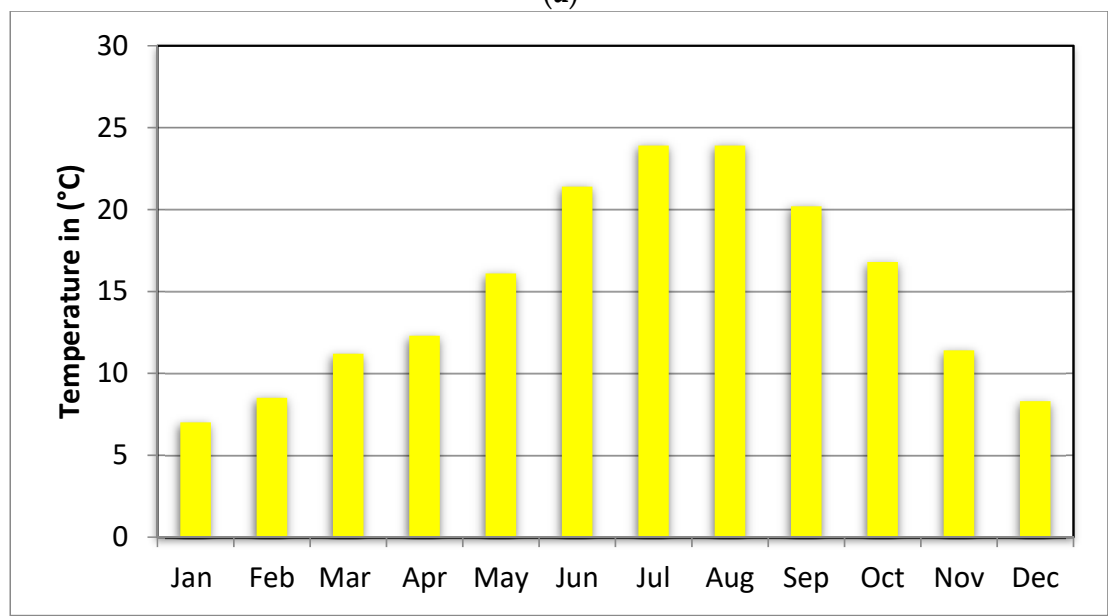

(b)

Figure 1. (a) Monthly average daily global radiation on a horizontal and tilted $30^{\circ}$ surface. (b) Monthly temperature in ${ }^{\circ} \mathrm{C}$.

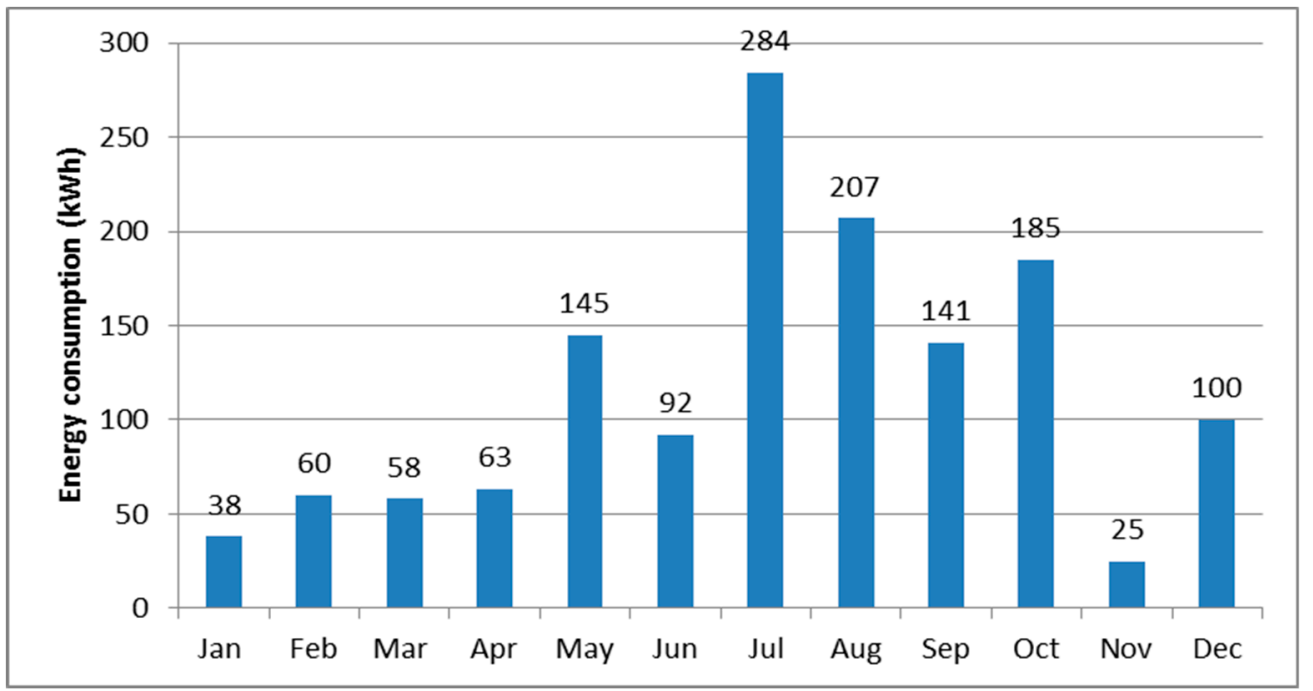

Figure 2. Annual energy consumption of a typical house during the year 2016. 
Table 2. Household daily electricity consumption.

\begin{tabular}{ccccc}
\hline $\begin{array}{c}\text { Header Types of } \\
\text { Electrical Consumption }\end{array}$ & Number & Power & Use (h/d) & Energy (Wh/d) \\
\hline Fluorescent lamps & 4 & 40 W/lamp & 5 & 800 \\
\hline TV/Video-tape PC & 1 & 250 W/app & 3 & 750 \\
\hline Domestic appliances & 5 & $100 \mathrm{~W} / \mathrm{app}$ & 2 & 1000 \\
\hline Fridge/Deep-freeze & 1 & - & $1000 \mathrm{Wh} / \mathrm{d}$ & 1000 \\
\hline Other uses & 1 & $141 \mathrm{~W}$ & 2 & 282 \\
\hline Daily total energy demand & - & - & - & 3832 \\
\hline
\end{tabular}

\subsection{Sizing Procedure}

The main components of the proposed SAPV System included a PV array, a charge controller, an inverter, a battery and a back-up generator diesel as shown in Figure 3. The description of these components is provided as follows:

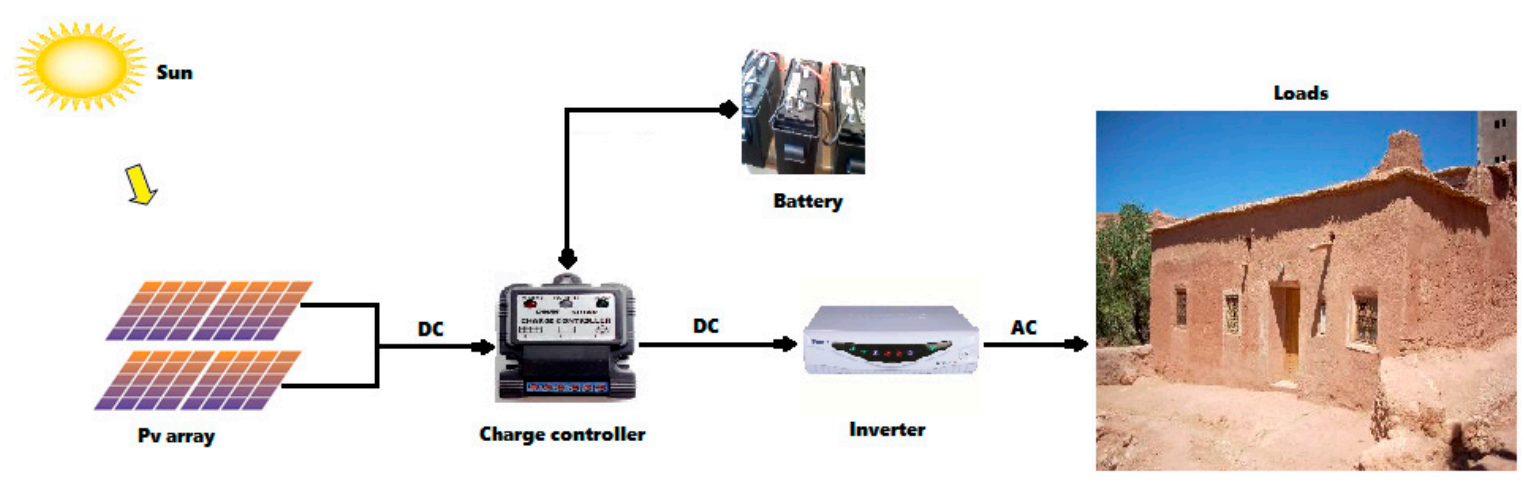

Figure 3. Layout of the proposed SAPV system.

\subsubsection{PV Module}

Solar modules are made of a number of PV cells connected in series and parallel circuits. The solar array is then a group of several modules electrically connected in a series-parallel combination to generate the required current and voltage $[62,63]$. When the PV circuit is closed, the freed electrons flow through an external circuit generating a DC current. Therefore, the current generated is directly dependent on the number of incoming photons and thus, the solar irradiation [64]. The surface area covered by the PV modules is calculated by the following equation [65]:

$$
S_{P V}=\frac{D_{\text {ele }}}{H_{\mathrm{avg}} \times \eta_{\mathrm{PV}} \times \eta_{\mathrm{b}} \times \eta_{\mathrm{inv}} \times \mathrm{T}_{\mathrm{cf}}}
$$

with $S_{P V}$ representing the area of the photovoltaic plant in $\left(\mathrm{m}^{2}\right), \eta$ with subscripts: PV, $b$, and inv denote efficiencies of PV panels, batteries and inverter, respectively. $\mathrm{H}_{\mathrm{avg}}$ is the average irradiation available per day $\left(\mathrm{kWh} / \mathrm{m}^{2} / \mathrm{d}, \mathrm{D}_{\text {ele }}\right.$ is daily electrical energy demand in $(\mathrm{kWh} / \mathrm{d})$ and the last term of the equation is the temperature correction factor represented by $\mathrm{T}_{\mathrm{cf}}$. The nominal power is given by [65-68] the following equation:

$$
\mathrm{P}_{\mathrm{PV}}=\mathrm{S}_{\mathrm{PV}} \times \mathrm{I}_{\mathrm{P}} \times \eta_{\mathrm{PV}}
$$

where $P_{P V}$ is the peak PV power and $I_{p}$ represents peak solar irradiance $\left(\mathrm{W} / \mathrm{m}^{2}\right)$. 


\subsubsection{Charge Controller, Inverters, Batteries, and Back-Up Diesel Generator}

The load controller regulates the energy levels of the batteries and the power supplied from the photovoltaic modules. These charge controllers not only increase the energy output of a photovoltaic system, but also optimize the charge of the batteries and hence extend their life significantly. To choose a charge controller, one has to consider two main elements; the voltage between the panels and the batteries, and the rated charge current. The autonomous photovoltaic system contains a solar inverter to convert a continuous voltage of $12 \mathrm{~V}, 24 \mathrm{~V}$, or $48 \mathrm{~V}$ batteries into alternating voltage of $220 \mathrm{~V}-240 \mathrm{~V}$ identical to that required by domestic electrical appliances. The battery is also an important component in a stand-alone photovoltaic system since it stores energy during the sunny hours and allows its use during night-time. For longer duration, the battery autonomy is based on the inverter and battery efficiencies and maximum allowed depth of battery discharge, denoted by $D_{d}$. Accordingly, the battery autonomy can be calculated from the following equation adopted from [68]:

$$
B_{c}=\frac{D_{\text {ele }} \times N_{\text {ccd }}}{\eta_{b} \times D_{d} \times \eta_{\text {inv }}}
$$

$\mathrm{N}_{\mathrm{ccd}}$ represents the number of continuous cloudy days.

When the SAPV is not able to meet the electrical load during cloudy/nights periods, a back-up diesel generator is activated.

\subsection{Economic Analysis}

The life cycle cost approach was adopted to check the viability of the designed SAPV system. This approach for the proposed system was based on the initial capital $\operatorname{cost} C_{i}$, the present value of maintenance/operation $\mathrm{C}_{\mathrm{OM}}$, and the present value of battery replacement $\operatorname{cost} \mathrm{C}_{\mathrm{BR}}$. It can be, therefore, expressed as [69-73]:

$$
\mathrm{L}_{\mathrm{cc}}=\mathrm{C}_{\mathrm{i}}+\mathrm{C}_{\mathrm{BR}}+\mathrm{C}_{\mathrm{OM}}
$$

The various other costs of the system components were determined based on the Moroccan market status (see Table 3). These costs are calculated based on the following equations:

$$
\begin{gathered}
\mathrm{C}_{\text {batt }}=\mathrm{S}_{\text {batt }} \times \mathrm{UC}_{\text {batt }} \\
\mathrm{C}_{\mathrm{PV}}=\mathrm{N}_{\mathrm{m}} \times \mathrm{PP}_{\mathrm{m}} \times \mathrm{UC}_{\mathrm{PV}} \\
\mathrm{C}_{\mathrm{inv}}=\mathrm{S}_{\mathrm{inv}} \times \mathrm{UC}_{\mathrm{inv}} \\
\mathrm{C}_{\mathrm{cc}}=\mathrm{S}_{\mathrm{cc}} \times \mathrm{UC}_{\mathrm{cc}}
\end{gathered}
$$

Table 3. Equipment costs used in the SAPV system.

\begin{tabular}{cccccc}
\hline Item & PV & Charge Controller & Battery & Inverter & Diesel Generator \\
\hline Cost & $1.02 \mathrm{USD} / \mathrm{W}_{\mathrm{p}}$ & $5.43 \mathrm{USD} / \mathrm{A}$ & $2.12 \mathrm{USD} / \mathrm{Ah}$ & $0.77 \mathrm{USD} / \mathrm{W}$ & $0.3 \mathrm{USD} / \mathrm{W}$ \\
\hline
\end{tabular}

On this basis, it is found that the price of the basic solar components (PV modules, batteries, inverter and charge controller) is equal to 4477.44 USD. To find the total initial investment $C_{i}$, it is necessary to consider the installation $C_{i n}$, other accessories $C_{\text {acc }}$ costs and cost of the diesel generator [55]:

$$
\mathrm{C}_{\mathrm{i}}=\mathrm{C}_{\mathrm{PV}}+\mathrm{C}_{\mathrm{inv}}+\mathrm{C}_{\mathrm{batt}}+\mathrm{C}_{\mathrm{cc}}+\mathrm{C}_{\mathrm{in}}+\mathrm{C}_{\mathrm{acc}}+\mathrm{C}_{\mathrm{DG}}
$$

The installation cost was assumed as $10 \%$ of the total cost of photovoltaic panels and the cost of the accessories was considered to be $5 \%$ of the initial PV panel cost.

Then the initial cost of the installation is $C_{i}=4858.68$ USD. Due to the lifetime of 20 years of the PV system, the batteries (with a lifetime of 5 years) must be replaced three times during the whole 
project life. Denoting the number of replacements by $r$, the present value of batteries replacement cost is expressed as [74]:

$$
C_{B R}=C_{B a t t} \sum_{j=1}^{r}\left(\frac{1+\mathrm{i}}{1+d}\right)^{\mathrm{Nj} /(1+\mathrm{r})}
$$

where $\mathrm{i}$ is the inflation rate and $\mathrm{d}$ is the discount rate are taken as $2.5 \%$ and $5 \%$, respectively, CFC means the cost fuel consumption. These values correspond to the Moroccan context. Therefore, $\mathrm{C}_{\mathrm{BR}}=3214.26$ USD. The operation and maintenance costs were taken as $1 \%$ of the total investment cost [75]. The present value of operation and maintenance cost can be noted as follows [76]:

$$
\mathrm{C}_{\mathrm{OM}}=\left[\mathrm{m} \times \mathrm{C}_{\mathrm{i}}+\mathrm{CFC}\right] \times\left(\frac{1+\mathrm{i}}{\mathrm{d}-\mathrm{i}}\right) \times\left[1-\left(\frac{1+\mathrm{i}}{1+\mathrm{d}}\right)^{\mathrm{N}}\right]
$$

$\mathrm{C}_{\mathrm{OM}}=2122.61 \mathrm{USD}$.

As a result, $\mathrm{L}_{\mathrm{cc}}=10,195.57 \mathrm{USD}$.

The unit cost of electricity is determined by Equation (12). In addition, the life cycle cost of the photovoltaic system was obtained from by Equation (13) as follows [77]:

$$
\begin{gathered}
\mathrm{COE}=\frac{\mathrm{AL}_{\mathrm{cc}}}{365 \times \mathrm{D}_{\text {ele }} \times \mathrm{S}_{\mathrm{f}}} \\
\mathrm{AL}_{\mathrm{cc}}=\mathrm{L}_{\mathrm{cc}} \times\left(\frac{1-\left(\frac{1+\mathrm{i}}{1+\mathrm{d}}\right)}{1-\left(\frac{1+\mathrm{i}}{1+\mathrm{d}}\right)^{\mathrm{N}}}\right)
\end{gathered}
$$

where $\mathrm{AL}_{\mathrm{cc}}$ is the annualized life cycle cost of the photovoltaic system, $\mathrm{L}_{\mathrm{cc}}$ is the life cycle cost, $\mathrm{D}_{\text {ele }}$ is the daily electrical demand, $\mathrm{COE}$ is the Cost Of Energy, and $\mathrm{S}_{\mathrm{f}}$ is the solar fraction.

\section{Results and Discussion}

\subsection{Preliminary Sizing Results}

To calculate the area of the PV fields, Equation (1) was used considering the following assumptions:

1. The cell temperature was assumed to reach $60^{\circ} \mathrm{C}$ with a TCF value of $80 \%$ [69].

2. Efficiencies of the inverter, battery, and PV modules were assumed to be $95 \%, 85 \%$, and $10.8 \%$; respectively.

3. To meet the energy demand, the PV power plant required a total area of $9.8 \mathrm{~m}^{2}$ of PV panels. From Equation (2), for a solar insolation of $1000 \mathrm{~W} / \mathrm{m}^{2}$, the peak photovoltaic power was calculated to be $1058.4 \mathrm{~W}_{\mathrm{p}}$. The selected PV module in this study is MSX-60 [78]. It contains 36 polycrystalline silicon cells in two strings each of 18 cells. The maximum power of this module is $60 \mathrm{~W}_{\mathrm{p}}$. The specifications of the PV module are summarized in Table 4 . A total of 18 modules was found to be enough to meet the entire energy demand of the case study house. The modules must be connected in two series and nine in parallel to ensure the compatibility of power, voltage and amperage.

The calculation of the battery capacity was performed using Equation (3). The number of continuous cloudy days $\left(\mathrm{N}_{\mathrm{ccd}}\right)$ was taken as three and the maximum permissible depth of battery discharge $\left(D_{d}\right)$ was assumed to be $85 \%$. So, the total capacity of the battery storage system was found to be $16,100 \mathrm{Wh}$. Taking a voltage of $24 \mathrm{~V}$ in the inverter entry, the total required ampere hours of the DC battery was calculated to be $670 \mathrm{Ah}$. If the selected battery's capacity and voltage are taken as $160 \mathrm{Ah}$ and $12 \mathrm{~V}$; respectively, the number of batteries will be four in total. Also, these batteries must be connected two in series and two in parallel.

Besides, it is necessary to have a charge controller that ensures safe charging to maintain long life of the batteries. In the present study, the load regulator was chosen so as to manage the maximum 
array current of $3.5 \times 9=31.5 \mathrm{~A}$. Concerning the last component of the system, the inverter should generally have a power rating which is $20 \%$ greater than the power of the total load. An inverter of $2400 \mathrm{~W}$ was selected to meet the maximum power of AC load.

Table 4. Module specifications.

\begin{tabular}{ccc}
\hline Characteristics & Unit & Rating \\
\hline Maximum power $\left(\mathrm{P}_{\max }\right)$ & $\mathrm{W}$ & 60 \\
Maximum power voltage & $\mathrm{V}$ & 17.1 \\
Maximum power current & $\mathrm{A}$ & 3.5 \\
Module efficiency & $\%$ & 10.8 \\
Short circuit current & $\mathrm{A}$ & 3.8 \\
Open circuit voltage & $\mathrm{V}$ & 21.1 \\
Number of cells & Pcs & 36 \\
\hline
\end{tabular}

\subsection{Annual Simulation of the Sized System}

PVsyst was used to carry out the annual simulation to predict the performance of the designed SAPV system. The simulation was made based on the following considerations:

1. Angle of inclination of modules $=30^{\circ}$ (optimum tilt angle for the considered location)

2. The PV modules were oriented to the south (azimuth $=0$ )

3. Meteorological data was generated by METEONORM

Solar energy to the user, back-up generator generated energy, and solar fraction are illustrated in Table 5. It is clearly seen that the designed system has the capability of meeting the electricity demand for almost the entire year with an average solar fraction of $79.1 \%$. The rest of the energy demand should be obtained by using the back-up generator.

Table 5. Power generation by the SAPV system.

\begin{tabular}{ccccc}
\hline Header The months & PV Contribution & DG Contribution & Total Load & Solar Fraction \\
\hline January & 37.9 & 0.1 & 38.0 & 0.998 \\
February & 60.0 & 0.00 & 60.0 & 0.999 \\
March & 57.9 & 0.1 & 58.0 & 0.998 \\
April & 62.9 & 0.1 & 63.0 & 0.999 \\
May & 138.5 & 6.5 & 145.0 & 0.955 \\
June & 91.9 & 0.1 & 92.0 & 0.999 \\
July & 147.1 & 136.9 & 284.0 & 0.518 \\
August & 147.2 & 59.8 & 207.0 & 0.711 \\
September & 132.5 & 8.5 & 141.0 & 0.940 \\
November & 116.7 & 68.3 & 185.0 & 0.631 \\
December & 25.0 & 0.0 & 25.0 & 0.998 \\
\hline Year & 88.9 & 11.1 & 100.0 & 0.889 \\
\hline Total & 1106.4 & 291.6 & 1398.0 & 0.791 \\
\hline
\end{tabular}

Based on the initial design and simulation processes, the cost of energy produced by the proposed SAPV system was found to be $0.57 \mathrm{USD} / \mathrm{kWh}$. This cost is relatively high compared to the current market standards and an optimization process was required to enhance the system design towards a more economically viable configuration.

\subsection{Optimization Results Using Homer Pro}

The SAPV generation system comprises four components including photovoltaic modules, a diesel generator, batteries, and converter to meet the energy needs of the home. Economic parameters were 
kept the same as mentioned earlier. The optimization process was carried out by Homer Pro software (3.10.3, Homer Energy, Colorado, USA version, manufacturer, city, state abbreviation if USA and Canada, Country). After a total number of runs of 77,986, the optimum configuration of the SAPV system was determined. It consists of $615 \mathrm{~W}$ photovoltaic models, $660 \mathrm{~W} \mathrm{DG}$, two accumulators $167 \mathrm{Ah}$ and $279 \mathrm{~W}$ for the capacity of the converter (see Figure 4). Obviously, since the PV capacity decreased compared to the first design, the capital cost decreases accordingly to 2568 USD. The unit energy cost was reduced considerably and is estimated to be $0.356 \mathrm{USD} / \mathrm{kWh}$ for this optimized configuration.

\begin{tabular}{|c|c|c|c|c|c|c|c|c|c|c|c|c|}
\hline \multicolumn{9}{|c|}{ Architecture } & \multicolumn{4}{|c|}{ Cost } \\
\hline$m$ & $E$ & 퉁 & z & $\underset{(\mathrm{kW})}{\mathrm{PV}} \nabla$ & $\begin{array}{l}\text { Gen } \nabla \\
(\mathrm{kW})\end{array}$ & $1 \mathrm{kWh}$ LI $\nabla$ & $\begin{array}{c}\text { Converter } \nabla \\
(\mathrm{kW})\end{array}$ & Dispatch $\nabla$ & $\underset{(\$)}{C O E} \odot \nabla$ & $\begin{array}{l}\mathrm{NPC} \\
(\$)\end{array} ;$ & $\begin{array}{c}\text { Operating cost } \\
\text { (\$) }\end{array}$ & $\begin{array}{c}\text { Initial capital } \nabla \\
\text { (\$) }\end{array}$ \\
\hline \multirow[t]{3}{*}{ 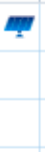 } & $E$ & 国阿 & $\tilde{z}$ & 0,615 & 0,660 & 2 & 0,279 & $C C$ & $0,356 \$$ & $7741 \$$ & $329,96 \$$ & $2568 \mathrm{~S}$ \\
\hline & $=$ & 国阳 & $\tilde{z}$ & & 0,660 & 2 & 0,438 & $C C$ & $0,498 \$$ & $10837 \$$ & $620,84 \$$ & $1103 \mathrm{~S}$ \\
\hline & $E$ & & & & 0,660 & & & $\triangle C$ & $0,728 \$$ & $15841 \$$ & $997,66 \$$ & $198,00 \mathrm{~S}$ \\
\hline 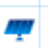 & $=$ & & $\tilde{z}$ & 0,00521 & 0,660 & & 0,00130 & $\triangle C$ & $0,729 \$$ & $15852 \$$ & $997,50 \$$ & $211,61 \$$ \\
\hline
\end{tabular}

Figure 4. Optimum system results.

Monthly average electric production by the optimized configuration is shown in Figure 5. It is clear that the optimized configuration is characterized by a lower solar fraction compared to the initial design (54.9\% vs 79.1\%). Therefore, at the present market status, using Diesel Generators to generate a part of the energy demand is an economically viable solution mainly due to provided subsidies given by the state to compensate conventional fuels.

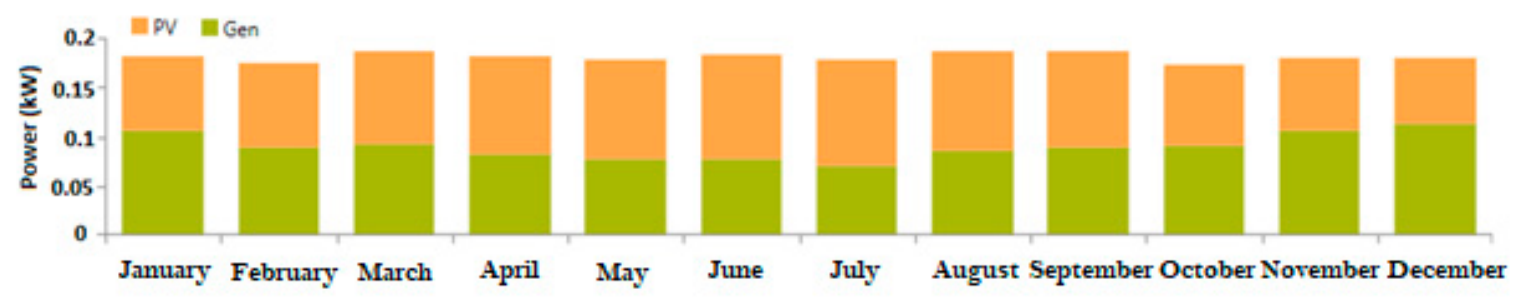

Figure 5. Monthly average electric production of the optimized configuration.

\section{Conclusions}

With the rapid pace of industrialization, growing population, and depletion of fossil fuel resources, it has become imperative to enhance the acceptance rate of solar energy technologies for household electrification. As the use of this technology is gaining popularity worldwide, it is worth exploring the suitable design and economic feasibility of stand-alone PV electrification system. Similar to many parts of the world suffering from lack of electricity, the option of an autonomous photovoltaic system is very critical for Africa's rural regions. Therefore, this paper presented a techno-economic performance of the proposed SAPV system for rural electrification in general and specifically for a house in Tazouta, Morocco. The major issue bound to widespread exploitation of this technology was the high initial cost; however, rapidly decreasing prices of PV modules improved its cost-competitiveness in comparison to conventional energy generation systems. This study contains the sizing of the complete SAPV system to decide the required capacity of the PV array, inverter, battery storage, and charge controller to fulfill the required load. Annual simulation was carried out based on hourly meteorological data to assess the system performance. The results derived from a series of simulations reveal that the proposed system is able to meet $3.8 \mathrm{kWh} / \mathrm{d}$ of daily electric load of the case study house for almost the entire year based on $1080 \mathrm{~W}_{\mathrm{p}}$ of total capacity of PV modules and $670 \mathrm{Ah}$ of battery storage of and with an average solar fraction of about $79.1 \%$. In order to assess the economic viability of the system for the end-users, a life cycle cost analysis of SAPV system was 
performed and it was found to be 10,195.56 USD. The initial cost and unit electricity cost were also computed and found to be 4,858.68 USD and 0.57 USD/kWh, respectively. An optimized solution was determined using Homer Pro tool indicating that the unit energy cost can fall to $0.35 \mathrm{USD} / \mathrm{kWh}$ by reducing the PV capacity to $615 \mathrm{~W}$ and increasing the share of the diesel generator. PV use of these systems may mitigate environmental pollution and afford remedial action especially in regions where air pollution rises to alarming levels [78]. As a result, Moroccan authorities should provide renewable energy subsidies to improve further the economic competitiveness of such systems.

Author Contributions: Conceptualization, methodology and software, H.E.-h. and A.A.; revision, S.R. and M.S.B.; visualization, A.J., B.E.A. and T.K.

Funding: This research did not receive any external funding.

Conflicts of Interest: The authors declare no conflict of interest.

\section{Nomenclature}

\begin{tabular}{|c|c|c|c|}
\hline $\mathrm{AL}_{\mathrm{cc}}$ & Annualized life cycle cost (USD) & $\mathrm{N}_{\mathrm{ccd}}$ & Number of continuous cloudy days \\
\hline $\mathrm{H}_{\text {avg }}$ & $\begin{array}{l}\text { Average irradiation available per day } \\
\left(\mathrm{kwh} / \mathrm{m}^{2} / \mathrm{d}\right)\end{array}$ & $\mathrm{N}_{\mathrm{m}}$ & Number of modules \\
\hline $\mathrm{B}_{\mathrm{c}}$ & Battery capacity (Ah) & $\mathrm{PP}_{\mathrm{m}}$ & Peak module power $(\mathrm{W})$ \\
\hline$S_{\text {batt }}$ & Battery size (Ah) & $\mathrm{P}_{\mathrm{pv}}$ & Peak PV power \\
\hline $\mathrm{S}_{\mathrm{cc}}$ & Charge controller size (A) & $\mathrm{I}_{\mathrm{pv}}$ & Peak solar irradiance $\left(\mathrm{W} / \mathrm{m}^{2}\right)$ \\
\hline $\mathrm{C}_{\mathrm{ac}}$ & Cost of accessories (USD) & PR & Performance ratio $(\%)$ \\
\hline$C_{\text {batt }}$ & Cost of battery (USD) & $\mathrm{G}_{0}$ & Reference irradiations $\left(\mathrm{W} / \mathrm{m}^{2}\right)$ \\
\hline $\mathrm{C}_{\mathrm{cc}}$ & Cost of charge controller (USD) & $\mathrm{Y}_{\mathrm{R}}$ & Reference yield (-) \\
\hline $\mathrm{C}_{\mathrm{in}}$ & Cost of installation (USD) & $S_{p v}$ & Surface area of PV system $\left(\mathrm{m}^{2}\right)$ \\
\hline $\mathrm{C}_{\mathrm{inv}}$ & Cost of inverter (USD) & $\mathrm{T}_{\mathrm{cf}}$ & Temperature correction factor $\left({ }^{\circ} \mathrm{C}\right)$ \\
\hline $\mathrm{C}_{\mathrm{OM}}$ & Cost of operation and maintenance (USD) & $\mathrm{UC}_{\text {batt }}$ & Unit cost of battery (USD) \\
\hline$C_{p v}$ & Cost of PV (USD) & $\mathrm{UC}_{\mathrm{cc}}$ & Unit cost of charge controller (USD) \\
\hline $\mathrm{C}_{\mathrm{BR}}$ & Cost of replacement batteries (USD) & $\mathrm{UC}_{\text {inv }}$ & Unit cost of inverter (USD) \\
\hline $\mathrm{D}_{\text {ele }}$ & Daily electrical demand (kwh/d) & $\mathrm{UC}_{\mathrm{pv}}$ & Unit cost of PV (USD) \\
\hline$\eta_{\mathrm{b}}$ & Efficiency of battery (\%) & $\mathrm{EC}_{\mathrm{u}}$ & Unit electricity cost (USD) \\
\hline$\eta_{\text {inv }}$ & Efficiency of inverter (\%) & & \\
\hline$\eta_{\mathrm{pv}}$ & Efficiency of PV panels (\%) & Abbreviations & \\
\hline $\mathrm{E}_{\mathrm{I}}$ & Energy incident $\left(\mathrm{kWh} / \mathrm{m}^{2}\right)$ & $\mathrm{ADB}$ & African Development Bank \\
\hline$C_{i}$ & Initial cost (USD) & $\mathrm{AC}$ & Alternating current \\
\hline$S_{\text {inv }}$ & Inverter size $(\mathrm{W})$ & DC & Direct current \\
\hline $\mathrm{L}_{\mathrm{CC}}$ & Life cycle cost (USD) & GHG & Greenhouse Gas \\
\hline $\mathrm{Y}_{\mathrm{F}}$ & Final yield (-) & GDPs & Gross Domestic Product society \\
\hline$D_{d}$ & $\begin{array}{l}\text { Maximum permissible depth of battery } \\
\text { discharge (-) }\end{array}$ & PV & Photovoltaic \\
\hline $\mathrm{E}_{\mathrm{AC}}$ & Net AC energy output (kWh) & $\begin{array}{l}\text { SAPV } \\
\text { USD }\end{array}$ & Stand-Alone Photovoltaic System \\
\hline
\end{tabular}

\section{References}

1. Allouhi, A. Energetic, exergetic, economic and environmental (4 E) assessment process of wind power generation. J. Clean. Prod. 2019, 235, 123-137. [CrossRef]

2. Iqbal, M.I.; Himmler, R.; Gheewala, S.H. Potential life cycle energy savings through a transition from typical to energy plus households: A case study from Thailand. Energy Build. 2017, 134, 295-305. [CrossRef]

3. Khatib, H. IEA world energy outlook 2011-A comment. Energy Policy 2012, 48, 737-743. [CrossRef]

4. Mandelli, S.; Barbieri, J.; Mattarolo, L.; Colombo, E. Sustainable energy in Africa: A comprehensive data and policies review. Renew. Sustain. Energy Rev. 2014, 37, 656-686. [CrossRef]

5. UNFPA, W.U. The World Bank: Trends in Maternal Mortality: 1990 to 2010; World Health Organization: Geneva, Switzerland, 2010; Volume 3.

6. Moyo, B. Power infrastructure quality and manufacturing productivity in Africa: A firm level analysis. Energy Policy 2013, 61, 1063-1070. [CrossRef] 
7. Kumar, S.; Pal, G.; Shah, T. High performance overhead power lines with carbon nanostructures for transmission and distribution of electricity from renewable sources. J. Clean. Prod. 2017, 145, 180-187. [CrossRef]

8. Ouedraogo, N.S. Modeling sustainable long-term electricity supply-demand in Africa. Appl. Energy 2017, 190, 1047-1067. [CrossRef]

9. Azimoh, C.L.; Klintenberg, P.; Wallin, F.; Karlsson, B.; Mbohwa, C. Electricity for development: Mini-grid solution for rural electrification in South Africa. Energy Convers. Manag. 2016, 110, 268-277. [CrossRef]

10. "Lights, Power, Action": AfDB's Adesina and Kofi Annan urge governments to close Africa's energy deficit. Available online: https://www.afdb.org/en/news-and-events/lights-power-action-afdbs-adesina-and-kofiannan-urge-governments-to-close-africas-energy-deficit-16789 (accessed on 13 March 2017).

11. Allouhi, A.; Buker, M.S.; El-houari, H.; Boharb, A.; Amine, M.B.; Kousksou, T.; Jamil, A. PV water pumping systems for domestic uses in remote areas: Sizing process, simulation and economic evaluation. Renew. Energy 2019, 132, 798-812. [CrossRef]

12. Allouhi, A.; Saadani, R.; Kousksou, T.; Saidur, R.; Jamil, A.; Rahmoune, M. Grid-connected PV systems installed on institutional buildings: Technology comparison, energy analysis and economic performance. Energy Build. 2016, 130, 188-201. [CrossRef]

13. Agrouaz, Y.; Bouhal, T.; Allouhi, A.; Kousksou, T.; Jamil, A.; Zeraouli, Y. Energy and parametric analysis of solar absorption cooling systems in various Moroccan climates. Case Stud. Therm. Eng. 2017, 9, $28-39$. [CrossRef]

14. Allouhi, A.; Agrouaz, Y.; Amine, M.B.; Rehman, S.; Buker, M.S.; Kousksou, T.; Benbassou, A. Design optimization of a multi-temperature solar thermal heating system for an industrial process. Appl. Energy 2017, 206, 382-392. [CrossRef]

15. Kousksou, T.; Allouhi, A.; Belattar, M.; Jamil, A.; El Rhafiki, T.; Zeraouli, Y. Morocco's strategy for energy security and low-carbon growth. Energy 2015, 84, 98-105. [CrossRef]

16. Allouhi, A.; Saadani, R.; Buker, M.S.; Kousksou, T.; Jamil, A.; Rahmoune, M. Energetic, economic and environmental (3E) analyses and LCOE estimation of three technologies of PV grid-connected systems under different climates. Solar Energy 2019, 178, 25-36. [CrossRef]

17. Murphy, J.T. Making the energy transition in rural East Africa: Is leapfrogging an alternative? Technol. Forecast. Social Chang. 2001, 68, 173-193. [CrossRef]

18. Narula, S.A.; Bhattacharyya, S. Off-grid electricity interventions for cleaner livelihoods: A Case study of value chain development in henkanal district of Odisha. J. Clean. Prod. 2017, 142, 191-202. [CrossRef]

19. Casillas, C.E.; Kammen, D.M. The energy-poverty-climate nexus. Science 2010, 330, 1181-1182. [CrossRef]

20. Said, Z.; Mehmood, A. Standalone photovoltaic system assessment for major cities of United Arab Emirates based on simulated results. J. Clean. Prod. 2017, 142, 2722-2729. [CrossRef]

21. Hepbasli, A. A key review on exergetic analysis and assessment of renewable energy resources for a sustainable future. Renew. Sustain. Energy Rev. 2008, 12, 593-661. [CrossRef]

22. El Fadili, A.; Giri, F.; El Magri, A. Reference voltage optimizer for maximum power point tracking in triphase grid-connected photovoltaic systems. Int. J. Electr. Power Energy Syst. 2014, 60, 293-301. [CrossRef]

23. Gautam, B.R.; Li, F.; Ru, G. Assessment of urban roof top solar photovoltaic potential to solve power shortage problem in Nepal. Energy Build. 2015, 86, 735-744. [CrossRef]

24. Shaahid, S.M.; Elhadidy, M.A. Economic analysis of hybrid photovoltaic-diesel-battery power systems for residential loads in hot regions-A step to clean future. Renew. Sustain. Energy Rev. 2008, 12, 488-503. [CrossRef]

25. Osma-Pinto, G.; Ordóñez-Plata, G. Measuring the effect of forced irrigation on the front surface of PV panels for warm tropical conditions. Energy Rep. 2019, 5, 501-514. [CrossRef]

26. Adeoti, O.; Oyewole, B.A.; Adegboyega, T.D. Solar photovoltaic-based home electrification system for rural development in Nigeria: Domestic load assessment. Renew. Energy 2001, 24, 155-161. [CrossRef]

27. Blum, N.U.; Wakeling, R.S.; Schmidt, T.S. Rural electrification through village grids-Assessing the cost competitiveness of isolated renewable energy technologies in Indonesia. Renew. Sustain. Energy Rev. 2013, 22, 482-496. [CrossRef]

28. Buker, M.S.; Riffat, S.B. Preliminary performance test of a combined solar thermal roof system with heat pump for buildings. Energy Procedia 2016, 91, 421-431. [CrossRef] 
29. Singh, A.; Baredar, P. Techno-economic assessment of a solar PV, fuel cell, and biomass gasifier hybrid energy system. Energy Rep. 2016, 2, 254-260. [CrossRef]

30. Palit, D. Solar energy programs for rural electrification: Experiences and lessons from South Asia. Energy Sustain. Dev. 2013, 17, 270-279. [CrossRef]

31. Rehman, I.H.; Kar, A.; Raven, R.; Singh, D.; Tiwari, J.; Jha, R.; Mirza, A. Rural energy transitions in developing countries: A case of the UttamUrja initiative in India. Environ. Sci. Policy 2010, 13, 303-311. [CrossRef]

32. Ibrahim, M.; Anisuzzaman, M.; Kumar, S.; Bhattacharya, S.C. Demonstration of PV micro-utility system for rural electrification. Solar Energy 2002, 72, 521-530. [CrossRef]

33. Bhandari, A.K.; Jana, C. A comparative evaluation of household preferences for solar photovoltaic standalone and mini-grid system: An empirical study in a costal village of Indian Sundarban. Renew. Energy 2010, 35, 2835-2838. [CrossRef]

34. Kaundinya, D.P.; Balachandra, P.; Ravindranath, N.H. Grid-connected versus stand-alone energy systems for decentralized power-A review of literature. Renew. Sustain. Energy Rev. 2009, 13, 2041-2050. [CrossRef]

35. Roy, A.; Kabir, M.A. Relative life cycle economic analysis of stand-alone solar PV and fossil fuel powered systems in Bangladesh with regard to load demand and market controlling factors. Renew. Sustain. Energy Rev. 2012, 16, 4629-4637. [CrossRef]

36. Nafeh, E.S.A. Design and economic analysis of a stand-alone PV system to electrify a remote area household in Egypt. Open Renew. Energy J. 2009, 2, 33-37. [CrossRef]

37. Oko, C.O.C.; Diemuodeke, E.O.; Omunakwe, N.F.; Nnamdi, E. Design and Economic Analysis of a Photovoltaic System-A Case Study. Int. J. Renew. Energy Dev. 2012, 1, 65. [CrossRef]

38. Ma, T.; Yang, H.; Lu, L. Performance evaluation of a stand-alone photovoltaic system on an isolated island in Hong Kong. Appl. Energy 2013, 112, 663-672. [CrossRef]

39. Chel, A.; Tiwari, G.N. A case study of a typical $2.32 \mathrm{~kW}$ P stand-alone photovoltaic (SAPV) in composite climate of New Delhi (India). Appl. Energy 2011, 88, 1415-1426. [CrossRef]

40. Mohammed, M.; Aziz, A.; Alwaeli, A.H.; Kazem, H.A. Optimal sizing of photovoltaic systems using HOMER for Sohar, Oman. Int. J. Renew. Energy Res. (IJRER) 2013, 3, 470-475.

41. Kaplani, E.; Kaplanis, S. A stochastic simulation model for reliable PV system sizing providing for solar radiation fluctuations. Appl. Energy 2012, 97, 970-981. [CrossRef]

42. Al-Karaghouli, A.; Kazmerski, L.L. Optimization and life-cycle cost of health clinic PV system for a rural area in southern Iraq using HOMER software. Solar Energy 2010, 84, 710-714. [CrossRef]

43. Bhandari, R.; Stadler, I. Electrification using solar photovoltaic systems in Nepal. Appl. Energy 2011, 88, 458-465. [CrossRef]

44. Kumar, A.; Mandapati, R. Designing and Lifecycle Assessment of SPV System for Conference Hall at Dept.of Energy 2012 MANIT, Bhopal. Computer (350W) 2012, 1, 6.

45. Byrne, J.; Zhou, A.; Shen, B.; Hughes, K. Evaluating the potential of small-scale renewable energy options to meet rural livelihoods needs: A GIS-and lifecycle cost-based assessment of Western China's options. Energy Policy 2007, 35, 4391-4401. [CrossRef]

46. Bataineh, K.; Dalalah, D. Optimal configuration for design of stand-alone PV system. Smart Grid Renew. Energy 2012, 3, 139-147. [CrossRef]

47. Bhuiyan, M.R.; Rahman, M.M.; Shaid, A.; Bashar, M.M.; Khan, M.A. Scope of reusing and recycling the textile wastewater after treatment with gamma radiation. J. Clean. Prod. 2016, 112, 3063-3071. [CrossRef]

48. Soufi, A.; Chermitti, A.; Triki, N.B. Sizing and optimization of a livestock shelters solar stand-alone power system. Int. J. Comput. Appl. 2013, 71, 4. [CrossRef]

49. Saxena, S.; Gaur, M.K.; Sinha, D.; Malvi, C.S.; Mishra, S. Design of photovoltaic system for ABiscuit packing machine. Int. J. Eng. Sci. Emerg. Technol. 2013, 6, 76-85.

50. Hassan, A.A.; Nafeh, A.A.; Fahmy, F.H.; El-Sayed, M.A. Stand-alone photovoltaic system for an emergency health clinic. In Proceedings of the International Conference on Renewable Energies and Power Quality ICREPQ, Granada, Spain, 23-25 March 2010; Volume 10.

51. Silva, S.B.; Severino, M.M.; De Oliveira, M.A.G. A stand-alone hybrid photovoltaic, fuel cell and battery system: A case study of Tocantins, Brazil. Renew. Energy 2013, 57, 384-389. [CrossRef]

52. Kaldellis, J.K.; Spyropoulos, G.C.; Kavadias, K.A.; Koronaki, I.P. Experimental validation of autonomous PV-based water pumping system optimum sizing. Renew. Energy 2009, 34, 1106-1113. [CrossRef] 
53. Use of Photovoltaic Systems for Rural Electrification in Thailand. Available online: http://www.icrepq.com/ icrepq07/352-Rapapate.pdf (accessed on 17 November 2019).

54. Leloux, J.; Narvarte, L.; Trebosc, D. Review of the performance of residential PV systems in Belgium. Renew. Sustain. Energy Rev. 2012, 16, 178-184. [CrossRef]

55. Askari, I.B.; Ameri, M. Techno-economic feasibility analysis of stand-alone renewable energy systems (PV/bat, Wind/bat and Hybrid PV/wind/bat) in Kerman, Iran. Energy Sources 2012 Part B Econ. Plan. Policy 2012, 7, 45-60. [CrossRef]

56. Vasisht, M.S.; Srinivasan, J.; Ramasesha, S.K. Performance of solar photovoltaic installations: Effect of seasonal variations. Solar Energy 2016, 131, 39-46. [CrossRef]

57. Ubertini, S.; Desideri, U. Performance estimation and experimental measurements of a photovoltaic roof. Renew. Energy 2003, 28, 1833-1850. [CrossRef]

58. Khatib, T.; Elmenreich, W. Optimum availability of standalone photovoltaic power systems for remote housing electrification. Int. J. Photoenergy 2014, 2014, 475080. [CrossRef]

59. METEONORM. Available online: http://METEONORM.com/ (accessed on 11 march 2014).

60. A Full Package for the Study of Your Photovoltaic Systems. Available online: http://www.pvsyst.com/fr/ (accessed on 12 March 2013).

61. Homer Energy. Available online: https://www.homerenergy.com/homer-pro.html (accessed on 17 October 2017).

62. Patel, M.R. Wind and Solar Power Systems-Design, Analysis, and Operation. Wind Eng. 2006, 30, $265-266$.

63. Pamparana, G.; Kracht, W.; Haas, J.; Díaz-Ferrán, G.; Palma-Behnke, R.; Román, R. Integrating photovoltaic solar energy and a battery energy storage system to operate a semi-autogenous grinding mill. J. Clean. Prod. 2017, 165, 273-280. [CrossRef]

64. Cucchiella, F.; D'Adamo, I.; Gastaldi, M. Photovoltaic energy systems with battery storage for residential areas: An economic analysis. J. Clean. Prod. 2016, 131, 460-474. [CrossRef]

65. Technoeconomics Analysis of A Photovoltaic System to Provide Electricity for A Household in Malaysia. Available online: https://www.researchgate.net/publication/306218167_Technoeconomics_analysis_of_a_ photovoltaic_system_to_provide_electricity_for_a_household_in_Malaysia (accessed on 17 November 2019).

66. Mahmoud, M.M.; Ibrik, I.H. Techno-economic feasibility of energy supply of remote villages in Palestine by PV-systems 2006 diesel generators and electric grid. Renew. Sustain. Energy Rev. 2006, 10, 128-138. [CrossRef]

67. Ghaib, K.; Ben-Fares, F.Z. A design methodology of stand-alone photovoltaic power systems for rural electrification. Energy Convers. Manag. 2017, 148, 1127-1141. [CrossRef]

68. Song, J.; Choi, Y. Design of photovoltaic systems to power aerators for natural purification of acid mine drainage. Renew. Energy 2015, 83, 759-766. [CrossRef]

69. Wang, C.; Nehrir, M.H. Power management of a stand-alone wind/photovoltaic/fuel cell energy system. IEEE Trans. Energy Convers. 2008, 23, 957-967. [CrossRef]

70. Ajao, K.R.; Ajimotokan, H.A.; Popoola, O.T.; Akande, H.F. Electric energy supply in Nigeria, decentralized energy approach. Cogener. Distrib. Gener. J. 2009, 24, 34-50. [CrossRef]

71. Ajan, C.W.; Ahmed, S.S.; Ahmad, H.B.; Taha, F.; Zin, A.A.B.M. On the policy of photovoltaic and diesel generation mix for an off-grid site: East Malaysian perspectives. Solar Energy 2003, 74, 453-467. [CrossRef]

72. Celik, A.N. Present status of photovoltaic energy in Turkey and life cycle techno-economic analysis of a grid-connected photovoltaic-house. Renew. Sustain. Energy Rev. 2006, 10, 370-387. [CrossRef]

73. Celik, A.N. Effect of different load profiles on the loss-of-load probability of stand-alone photovoltaic systems. Renew. Energy 2007, 32, 2096-2115. [CrossRef]

74. Kolhe, M.; Kolhe, S.; Joshi, J.C. Economic viability of stand-alone solar photovoltaic system in comparison with diesel-powered system for India. Energy Econ. 2002, 24, 155-165. [CrossRef]

75. Kamali, S. Feasibility analysis of standalone photovoltaic electrification system in a residential building in Cyprus. Renew. Sustain. Energy Rev. 2016, 65, 1279-1284. [CrossRef]

76. Buker, M.S.; Mempouo, B.; Riffat, S.B. Performance evaluation and techno-economic analysis of a novel building integrated PV/T roof collector: An experimental validation. Energy Build. 2014, 76, 164-175. [CrossRef] 
77. Agrawal, B.; Tiwari, G.N. Life cycle cost assessment of building integrated photovoltaic thermal (BIPVT) systems. Energy Build. 2010, 42, 1472-1481. [CrossRef]

78. MSX-60 60 Watt \& MSX-64 64 Watt Polycrystalline Solar Panel. Available online: https://www. solarelectricsupply.com/solarex-msx-60-w-junction-box-551 (accessed on 17 November 2019).

(C) 2019 by the authors. Licensee MDPI, Basel, Switzerland. This article is an open access article distributed under the terms and conditions of the Creative Commons Attribution (CC BY) license (http://creativecommons.org/licenses/by/4.0/). 